\title{
Factors Affecting Agro-Pastoralist and Pastoralists' Willingness to Adopt Beef Cattle Fattening in the Lake Zone in Tanzania
}

\author{
Sophia Nyakunga Mlote ${ }^{1}$, Ntengua Selemani Mdoe $^{2}$, Aida Cuthbert Isinika ${ }^{3} \&$ Louis Asumani Mtenga $^{4}$ \\ ${ }^{1}$ Ministry of Livestock and Fisheries Development, Dar es Salaam, Tanzania \\ ${ }^{2}$ Department of Agricultural Economics and Agribusiness, Sokoine University of Agriculture, Morogoro, \\ Tanzania \\ ${ }^{3}$ Institute of Continuing Education, Sokoine University of Agriculture, Morogoro, Tanzania \\ ${ }^{4}$ Department of Animal Science and Production, Sokoine University of Agriculture, Morogoro, Tanzania \\ Correspondence: Sophia Nyakunga Mlote, Ministry of Livestock and Fisheries Development, P.O. Box 9152, Dar \\ Es Salaam, Tanzania, East Africa. Tel: 255-753-362-502. E-mail:sophiamlote@gmail.com
}

Received: July 9, 2013 Accepted: August 5, 2013 Online Published: September 15, 2013

doi:10.5539/jas.v5n10p140

URL: http://dx.doi.org/10.5539/jas.v5n10p140

\begin{abstract}
The study investigated the factors affecting Agro-pastoralists and Pastoralists willingness to adopt beef cattle fattening technology in Shinyanga and Mwanza regions of the lake zone in Tanzania. Data were collected from Agro-pastoralist and Pastoralist using structured questionnaire administered to 401 randomly selected cattle keepers. Eight districts were involved; five in Shinyanga region (Kahama, Kishapu, Meatu, Bariadi, Maswa) and three in Mwanza region (Nyamagana, Sengerema, Magu). Data were analyzed using descriptive statistics and binary logistic regression model. Results from this analysis indicate that $93.5 \%$ of the respondents were willing to fatten their cattle if given an opportunity, while $14.7 \%$ had already started to fatten their cattle ranging from 30 to 100 animals per fattening cycle of three to four months. The results further indicated that the major factors influencing adoption of beef cattle fattening were marital status $(p<0.1)$, awareness $(p<0.05)$ and attitude towards the technology $(\mathrm{p}<0.01)$. Being married and being aware of the fattening technology increased the likelihood of adoption by $6.3 \%$ and $11.3 \%$ respectively. Mean while, a one unit change in attitude towards beef cattle fattening increased the likelihood of adoption by $0.3 \%$. The major constraints limiting beef cattle fattening were lack of skills $(22.6 \%)$, shortage of credit (20.4\%), high costs of fattening (17\%), limited availability of feeds $(14.2 \%)$ and lack of infrastructure (e.g. water dam/borehole, roads, cattle dip, veterinary centers)that are adapted for fattening $(12.4 \%)$.
\end{abstract}

Keywords: agro-pastoralists, adoption, beef cattle fattening, logit model, pastoralists, willingness to adopt

\section{Introduction}

Livestock production in Tanzania originates from a large resource base composed of different livestock species, breeds and types whose ownership and distribution differ from region to region. Three livestock production systems are commonly distinguished in the rangeland areas: commercial ranching, pastoralism and agro-pastoralism. Commercial ranching accounts for only $2 \%$ of the total cattle herd which is practiced by the National Ranching Company (NARCO). There are also a few (but rising number) private commercial ranches existing in different regions of the country most have few numbers raging from 4 to 330 (Mlote, Mdoe, Isinika and Mtenga, 2013). Pastoralism and Agro-pastoralism represent the traditional herd owned by small scale farmers which accounts for the remaining $98 \%$ of total cattle herd in the country. Pastoralism is concentrated in the northern plains of the country and is practiced in traditional grazing areas where climatic and soil conditions do not favor crop production. In this system livestock play a triple role; providing means for subsistence, serving as a store of wealth and a source of cash income. Agro-pastoralism involves cultivation of a range of crops and livestock keeping. This production system is thriving in many parts of the country due to the synergy between livestock and crops. Livestock production in these systems has been increasing at more than $2 \%$ per annum (Ministry of Livestock and Fisheries Development-MLFD, 2012). According to the 2007/2008 National Sample Census of Agriculture (NSCA), the number of cattle in Tanzania mainland increased from 16,837,150 in 2002/03 to $21,101,177$ in $2007 / 08$ making the country third largest in having stock of cattle in Africa, after Sudan and 
Ethiopia; and first in the SADC Region (MLDF, 2011). However, these animals are characterized by low growth rates, high mortality rates, low production and reproductive rates, low off-take rates and poor quality of the final products (meat, hides and skins and milk as a by-product), which makes it difficult for the cattle keepers and traders to access niche markets in the region and beyond (Ministry of Livestock Development-MLD, 2006). Cattle management practices to improve cattle production and productivity such as Artificial Insemination (AI) and beef cattle fattening not practiced in the traditional cattle herd in the country.

Recently, the government has shown interest to improve the traditional cattle herd in order to assist cattle keepers and traders to access niche markets through various interventions that are geared to turn the vast traditional herd of cattle (as well as goats and sheep) into an important revenue generating resource. This entails providing an avenue for actors in the traditional livestock production systems (agro pastoralist and pastoralist) to add value to their animals through beef cattle fattening by improving feed management. This would raise the income of pastoralists and agro- pastoralists, consequently their livelihoods. Such improvement would also facilitate achievement of targets set under the National Strategy for Growth and Reduction of Poverty -NSGRP (MLD, 2006; MLFD, 2011), which are consistent with the Millennium Development Goals (MDGs) in relation to overcoming food insecurity and income poverty.

Since 1990's, the government has made various efforts to provide an enabling environment for commercializing the livestock sector. As a first step, the government formulated a National Livestock Policy of 2006 along with the corresponding Livestock Development Strategy of 2010 and program of 2011. These documents address and articulate the necessary actions for revitalizing the sector. In the cattle sub sector, one of the strategies was to promote private ranching. To facilitate this, the National Ranching Company (NARCO) has subdivided some of its ranches into pieces of 2000-4000 hectares each capable of holding over 120,000 beef cattle and subleased them to local investors for commercial cattle farming. The strategy also entails establishing a system for livestock identification, registration and traceability through the supply chain; and promoting beef cattle fattening through a feedlot system. However, the adoption of beef cattle fattening by supply chain actors has been very low. According to the MLDF (2012) a total of 132, 229 cattle were fattened in 2012 of which $46.6 \%$ were in Mwanza, Shinyanga and Kagera regions in the Lake zone. This represents only $0.6 \%$ of all the cattle in the country. Thus far, there have been no studies in the country to establish important factors that impede the adoption process. Understanding these factors would also contribute to ongoing efforts to improve the livestock sector in terms of enabling policies as well as technologies which will accelerate transformation of the livestock sector in a manner that it serves as a pathway out of poverty for agro-pastoralists and pastoralists while also sustaining the environment.

This study examined the determinants of adopting beef cattle fattening in Shinyanga and Mwanza regions of the Lake Zone in Tanzania. The specific objectives of the study were (i) to analyze the willingness of agro-pastoralist and pastoralists in the Lake zone to adopt beef cattle fattening (ii) to estimate the number of animals they would be willing to fatten (iii) to determine factors that influence agro-pastoralists' and pastoralists' decision to adopt beef cattle fattening as an alternative or complementary technology in their livestock production system (iv) to determine constraints that limit agro-pastoralist and pastoralist to adopt beef cattle fattening.

The paper is organized in five major sections. In the next section the paper briefly discusses recent development on beef cattle fattening in Tanzania. This is followed by a brief review of technology adoption theory in the third section. The fourth section describes the methodology including the theoretical model and the empirical model in which hypotheses regarding the determinants of whether a farmer adopts beef cattle fattening or not. The rest of the paper discusses the results and presents conclusions and policy implications.

\section{Beef Cattle Fattening in Tanzania}

Beef cattle fattening is a new technology for smallholder farmers in Tanzania, being practiced by the National Ranching Company (NARCO) farms and few private entrepreneurs in Mwanza, Shinyanga, Kagera, Tabora, Singida, Dodoma, Arusha, Manyara, Rukwa and Iringa regions (MLDF, 2013). Within the Lake Zone, beef cattle fattening started during 1996 when there was shortage of pasture due to recurrent drought (July-December months) and an increasing number of cattle in the area. At the same time agricultural by-products in the form of cotton seed cake and husks were freely available from cotton oil processing plants. Innovative farmers used this opportunity to establish rudimentary feedlots for cattle fattening, using the factory by-products to supplement limited grazing pasture around the site of the established feedlot.

Beef cattle fattening as practices by the innovative entrepreneurs involves buying lean mature animals that are above 4 years old, often from primary livestock markets. These are fed crop by-product (cotton seed cake, cotton 
halls, and sunflower seed cake) and local minerals for about two to three months, after which they are sold at secondary livestock markets for higher prices. This has provided significant economic benefits to the entrepreneurs (Mlote et al., 2013). Apart from ensuring food security, beef cattle fattening also provides employment, investment opportunities; manure for sustainable agriculture and income generation through sale of fattened beef cattle from accrued enterprises profits (Mlote et al., 2013).

It would be expected that such returns would attract more followers and late adopters to enter into this seemingly lucrative business. However, as indicated earlier, the beef cattle fattening technology is spreading rather slowly, only $0.6 \%$ of the beef cattle herd are fattened cattle in the country. This raises the question: Are there any barriers to entry that can be addressed through policy and institutional changes? Such question calls for the need to investigate factors that limit the adoption of this technology. The technology could provide an assured outlet of cattle from the traditional herd into growing urban and export markets, thereby contributing to reducing poverty among pastoralists and agro-pastoralist in the country.

\section{Technology Adoption Theory}

Technology adoption involves an effective process that begins when an individual or operator learns about an innovation and ends at the final adoption stage (Hall, Dennis, Lopez, \& Marshall, 2009). According to Kilima, Mbiha, Erbough, Larson (2010), adoption is defined as a process where potential adopters go through technical evaluation of the technology in relation to the economic and social factors associated with using the technology. This process is often characterized by considerable uncertainty about potential benefits, costs and future profits streams from technology adoption.

Three models are commonly used to analyze technology adoption: innovation diffusion, economic constraints, and the adoption perspective. Diffusion of innovations is a theory that seeks to explain how, why, and at what rate new ideas and technology spread through cultures (Rogers, 1962). Rogers, 1962 defined diffusion as the process by which an innovation is communicated through certain channels over time among the members of a social system. The origin of the diffusion of innovations theory is varied and spans multiple disciplines. Rogers (1962) espoused the theory that there are four main elements that influence the spread of a new idea: the innovation, communication channels, time, and a social system. This process relies heavily on human capital. The innovation must be widely adopted in order to self-sustain. In the course of adoption, there is a point at which an innovation reaches a critical mass of adopters, which include: innovators, early adopters, early majority, late majority, and laggards (Rogers, 1962, p. 150). Diffusion of innovations manifests itself in different ways in various cultures and fields and is highly subjective to the type of adopters and innovation-decision process. The model treats diffusion of technology as a disequilibrium (influenced by market imperfection) or equilibrium (not influenced by market imperfection) process. The disequilibrium process suggests that the number of adopters will increase as information is generated during the implementation phase and spreads to other potential adopters generating an S-shaped diffusion rate curve with time. This increase will occur as long as the stock of knowledge increases, and may eventually decrease as the technology depreciates or become obsolete (Kilima et al., 2010). The equilibrium process assumes innovation diffusion to be asymmetric, which may not always be the case because benefits realized from technology adoption may vary across the firms due to firm size, input costs and the technology sophistication.

The economic constraints model suggests that resource endowments play an important role in technology adoption and that the capacity to adopt new technologies may be affected by limited access to agricultural resources such as human and physical capital (Nzomoi, Byaruhanga, Maritin, \& Omboto, 2007). Technologies in this case diffuse at different rate based on the relative prices of resources that are needed to support adoption. It is therefore, expected that early adopters would be those with most severe resource constraints, while those with ample or less expensive resources may refrain from doing so particularly in the early stages of adoption (Kilima et al., 2010).

The adoption perspective model suggests that technology adoption is influenced by perception of attributes and other benefits derived from its use. The model aims at soliciting respondents' views about innovations and where possible identifying ways through which these perceptions can be integrated into agricultural research and extension services. However, direct quantification of farmers' perceived utility from adopting new technology has always been difficult. Consequently several studies use estimates of probabilities to adopt technologies as a proxy for preferences (Tamrat, 2007; Hall, 2009; Johnson, Doye, Lalman, Peel, Raper, \& Chung, 2010; Sulo, Koech, Chumo, \& Chapng'eno, 2012).

The three models presented above, reveal different causes for technology adoption. However, in many cases, farmers may not adopt a technology for a variety of reasons and therefore it is difficult to pinpoint the model that 
most closely reflects farmers' decision making. Thus, the choice of empirical model might suffer from identification problems. The econometric inference problem is to identify factors that influence farmers' decision making. The specification adopted by this study encompasses elements from each of the three dominant models.

\section{Methodology}

\subsection{Theoretical Model}

Adoption of specific technologies is an individual producers' decision. A producer's utility from adopting a technology may be modeled as a linear function of the producers characteristics and the attributes of the technology. The probability that a producer will choose to adopt a particular technology is given by the probability that the utility of the alternative is greater than the utility that the producer would gain from any other given alternative. In making the decision to adopt or not adopt the producer chooses the alternative that maximizes utility (Kennedy, 1998). Following Rahm and Huffman (1984), the utility maximization function is specified as:

$$
\operatorname{Max}(U)=U\left(F C_{j i}, T A_{j i}\right.
$$

where $\mathrm{U}($.$) is the non-observable utility function that ranks the preference of the \mathrm{i}^{\text {th }}$ farmer for the $\mathrm{j}^{\text {th }}$ technology ( $\forall j=1,2) ; 1$ for improved and 2 for traditional technologies. The FC is defined as farm and farmer specific attributes and TA is defined as other attributes of the innovation that may be unobserved to the analyst but observed and acted upon by the decision maker. The basic assumption in Equation (1) is that smallholder farmers perceive the innovation as an optimum course of action to maximize their expected utility and the decision is made in a situation where the decision maker is fully aware of the technology and its attributes. This utility function also assumes that decision makers are able to screen new innovations based on local circumstances. The relation between the utility derived from $\mathrm{j}^{\text {th }}$ technology is therefore a function of FC, TA and a disturbance term with zero mean. Equation (1) can therefore be presented as:

$$
U_{j i}=\alpha_{j} F_{i}\left(M_{i}, A_{i}\right)+\varepsilon_{j i} \ldots \ldots \ldots \ldots \ldots . . \forall(j=1,2 ; i=1,2, \ldots, n)
$$

Since the respondents' utilities $U_{j i}$ are random, the $i^{\text {th }}$ farmer will select the alternative $j=1$ when $U_{1 i}>U_{2 i}$ or the non-observable random variable $\mathrm{Y}^{*}=\mathrm{U}_{1 \mathrm{i}}-\mathrm{U}_{2 \mathrm{i}}>0$.

The probability that the farmer adopts an improved technology $\left(\mathrm{Y}_{\mathrm{i}}=1\right)$ is a function of the independent variables and is represented as:

$$
\begin{aligned}
& P_{i}=P_{r}\left(Y_{i}=1\right)=P_{r}\left(U_{1 i}>U_{2 i}\right) \\
& =\operatorname{Pr}\left[\alpha_{j} F_{i}\left(M_{i}, \forall_{i}\right)+\varepsilon_{1 i}>\alpha_{j} F_{i}\left(M_{i}, \forall_{i}\right)+\varepsilon_{2 i}\right] \\
& =\operatorname{Pr}\left[\varepsilon_{1 i}-\varepsilon_{2 i}>F_{i}\left(M_{i}, \forall_{i}\right)\left(\alpha_{2}-\alpha_{1}\right)\right] \\
& =\operatorname{Pr}\left[\mu_{i}>F_{i}\left(M_{i}, \forall_{i}\right) \beta\right] \\
& =F\left(X_{i} \beta\right)
\end{aligned}
$$

Where $\mathrm{X}$ is an the $\mathrm{n} \times \mathrm{k}$ matrix of the explanatory variables and $\beta$ is a $\mathrm{kx} 1$ vector of parameters to be estimated, $\mathrm{P}_{\mathrm{r}}($.$) is a probability function, \mu_{i}$ is a random error term, and $\mathrm{F}(\mathrm{Xi} \beta)$ is the Cumulative Distribution Function (CDF) for $\mu_{i}$ evaluated at Xi $\beta$. Equation (3) indicates that the probability that a farmer will adopt an improved technology is a function of the vector of explanatory variables, unknown parameters and the error term.

The Function (F) in Equation (3) may take the form of a normal, logistic or probability function. Following Pindyck and Rubinfeld (1998) the logistic model uses a logistic cumulative function which always takes values between zero and one to estimate the probability as follows:

$$
f(t)=\frac{e^{t}}{e^{t}+1}=\frac{1}{1+e^{-t}}
$$

Viewing $t$ as a linear function of an explanatory variable $x$, we have:

$$
\pi(X)=\frac{e^{\left(\beta_{0}+\beta_{1} X\right)}}{e^{\left(\beta_{0}+\beta_{1} X\right)}+1}=\frac{1}{1+e^{-\left(\beta_{0}+\beta_{1} X\right)}}
$$


We also define the inverse of the logistic function, the Logit function as:

$$
g(x)=\operatorname{In} \frac{\pi(X)}{1-\pi(X)}=\beta_{0}+\beta_{1} X
$$

and equivalently:

$$
\frac{\pi(X)}{1-\pi(X)}=e^{\left(\beta_{0}+\beta_{1} X\right)}
$$

Where,

$\mathrm{g}(\mathrm{x})$ refers to the logit function of some given predictor $\mathrm{X}$, Ln denotes the natural logarithm, $\pi(\mathrm{X})$ is the probability that the dependent variable equals $1, \beta_{0}$ is the intercept from the linear regression equation, $\beta_{1} X$ is the regression coefficient multiplied with some value of the predictor, base $e$ denotes the exponential function. The logistic function is useful because it can take as an input any value ranging from negative infinity to positive infinity, whereas the output is confined to values between 0 and 1 .

Equation (4) illustrates that the probability of the dependent variable equal to 1, is equal to the value of the logistic function of the linear regression expression. This is important in that it shows that the input of the logistic regression equation (the value of the linear regression expression) can vary from negative to positive infinity and yet, after exponentiation the odds of the expression, the output will vary between zero and one. Equation 6 illustrates that the Logit function (i.e., log-odds or natural logarithm of the odds) is equivalent to the linear regression expression. Likewise, equation 7 illustrates that the odds of the dependent variable being equal to 1 is equivalent to the exponential function of the linear regression expression. This illustrates how the Logit function serves as a link function between the probability and the linear regression expression. Given that the Logit function falls within the interval $(1,0)$, it provides an adequate criterion upon which to conduct linear regression and the Logit function is easily converted back into the odds for adoption.

According to Green (2008) the probability model is a regression of the conditional expectation of $\mathrm{Y}$ on $\mathrm{X}$ giving the following equation;

$$
E(Y / X)=1\left[F\left(\beta^{\prime} X\right)\right]+0\left[1-F\left(\beta^{\prime} X\right)\right]=F\left(\beta^{\prime} X\right)
$$

Since the model is non-linear, the parameters are not necessarily the marginal effects of the various independent variables. The relative effect of each of the independent variables on the probability of adoption is obtained by differentiating equation (8) with respect to $X_{\mathrm{ij}}$ resulting into equation (9) (Green, 2008).

$$
\frac{\partial P_{i}}{\partial X_{i j}}=\left[\frac{\lambda^{\beta^{\prime} X}}{\left(1+\lambda^{\beta^{\prime} X}\right)^{2}}\right] \beta=F\left(\beta^{\prime} X\right)\left[1-F\left(\beta^{\prime} X\right)\right] \beta
$$

The marginal effect measures the effect on the conditional mean of $y$ of a change in one of regressors say $X_{j}$, which provides a good approximation of the amount of change in y resulting from one-unit change in $X_{k}$. The goodness of fit in this case is examined using the pseudo $\mathrm{R}^{2}$ and Mc Fadden $\mathrm{R}^{2}$ values (SAS, 1994).

\subsection{Empirical Model}

The study applies the logit or logistic model to estimate factors that affect adoption of beef cattle fattening for pastoralists and agro-pastoralists in the study area. The Logit model was chosen over the probit model because of its simplicity and easy of interpretation in that the logistic CDF is very simple, while the normal CDF involves an unevaluated integral. The inverse linearizing transformation for the Logit model, $\left[\wedge^{\left.-1_{(\pi)}\right]}\right.$, is directly interpretable as a log-odds, while the inverse transformation for probit $\left[\Phi^{-1}(\pi)\right]$, does not have a direct interpretation. Furthermore, the Logit model is a standard method for understanding the association between explanatory variables and a binary dependent variable (Green, 2003).

Logit model was used in this study to determine factors that influence adoption of cattle fattening technology. The dependent variable in this case was the willingness to adopt beef cattle fattening technology, denoted as " $y$ ", while the hypothesized independent variables were age, gender, marital status, household size, education level, herd size, attitude of the household head, awareness on beef cattle fattening, main source of income and location of the respondents. The explanatory variables were selected on the basis of the three models used to analyze technology 
adoption as described in section 3.0 above. The effect of each of these variables on the respondents' decision to adopt or not to adopt beef cattle fattening in the study area is discussed in the next section.

According to Akudugu, Guo, Dadzie (2012) age is an important factor that influences the probability of adoption of new technologies because it is said to be a primary latent characteristic in adoption decisions. However, there is contention on the direction of the effect of age on adoption. Previous studies which examined the role of age on adoption, found that the age of the household head could have a negative or positive effect on technology adoption because as age increases farmers become more risk averse and hence less willing to adopt new technologies signifying a negative influence on adoption (Hall et al., 2009; Kilima et al., 2010; Johnson et al., 2010; Qualls, 2011; Jing-na \& Lu-tang, 2012; Howley, Donoghue, \& Heanue, 2012). On the other hand, it was found that, as farmers' age increases, they accrued experience and became more aware of benefits associated with improved technologies and hence had positive influenced on technology adoption (Sajjad, Saif, \& Humayoun, 2009; Ward et al., 2008). Age in this study was assumed to influence the choice to engage in beef cattle fattening through experience in livestock rearing in relation with the socio-cultural roles prevailing in the study area. Age in a traditional society is an important indicator of one's position in society. Older agro-pastoralists are more deeply attached to traditional ways of rearing cattle than younger agro-pastoralist. In this study, the age of the household head (measured in years) is hypothesized to be negatively related with the adoption of beef cattle fattening.

The role of gender and marital status in technology adoption are contentious issues in the adoption literature. The literature suggest that women's role in agriculture production is increasingly important particularly as the number of female headed households in the rural areas of Sub-Saharan Africa increases (Kilima et al., 2010). Gender was a more pronounced characteristic in the study area where men are the main decision makers and women were decision maker only if were divorced or widowed and hence this variable was hypothesized to be positively influenced. Marital status is another increasingly important variable that may impact on technology adoption. Married couples tend to support each other in making decision, making them more likely to accept the positive side of new and emerging technologies. Married head of households are also expected to have more resources. This variable is expected to be positively associated with the adoption of new technologies.

Household size is another important variable in explaining technology adoption. Agro-pastoralists and pastoralist use family labor for most of the activities related to livestock rearing (grazing, watering, trekking, milking, tending to calves, treatment etc.). Most of the livestock management activities are easily done by family members (Tamrat, 2007). For this reason, large families are desirable. Adopting beef fattening introduces an additional activity into the family. It would be expected that larger families would be more easily inclined to adopt than smaller families. Family size takes a continuous value measured by the number of members within the households. Family size is hypothesized to have positive influence on decision to beef cattle fattening.

The level of education of households' heads is assumed to increase the ability to obtain, process, and use information relevant for adopting of beef cattle fattening. The education level of the respondents was a continuous variable which, ranges from zero to post-college education and it is a continuous variable. According to Kafle, (2010) and Dzadze, Osei, Aidoo and Nurah, (2012), the level of adoption was found to be positively influenced by the level of education. Ward et al. (2008) also found a positive and significant association between age, education and income from beef farming and adoption of technology. Contrary to previous research findings, education levels did not always had a positive impact on adoption probabilities, Interestingly, Johnson et al. (2010) found that education levels beyond a high school education negatively influenced the use of futures, options and/or cash contract. Based on previous studies, education is assumed to have a direct and positive influence on adoption of beef cattle fattening technology.

The number of Livestock Units is a proxy of the farmers' wealth and as such relates directly to their investment capacity to adopt new technologies (Kaliba et al., 2000). In this study, the number of livestock units or Tropical Livestock Unit (TLU) was assumed to take a continuous value, was calculated as prescribed by Tamrat (2007). Accordingly one (1) TLU is equivalent to one cattle of approximately $250 \mathrm{~kg}$ or above, 5 calves, 5 goats/ sheep. The total number and type of livestock species within a household within a village is a proxy of their relative wealth status (relative to other villagers). It is expected that households with larger TLU would be more inclined to take risks, such as venturing into adopting new technologies, including beef fattening. It is therefore expected that agro-pastoralists with higher TLU to be willing to accept beef cattle fattening, thus a positive coefficient is expected for this variable.

Past studies have established significant and positive relationships between awareness and adoption of technologies (Hall, 2009, Emukule, Ngigi, \& Guliye, 2011; Al-Hassan, Egyir, \& Abakar, 2013). A study by Prokopy, Floress, Klotthor-Weinkauf, Baumgart-Getz, 2008 indicated that education levels, capital, income, farm 
size, access to information, positive attitudes, awareness and utilization of social networks are generally positively, associated with the adoption of best management practices. Further more, an analysis of the use of Artificial Insemination (AI) for Ugandan dairy farmers revealed that the farmer's age, years of awareness of the AI technology, total farm milk production and sales, extension visits per year, and quality of AI services provided to the farmers were positively associated with adoption and use of AI technology (Kaaya, Bashaasha, \& Mutetikka, 2005). Based on such previous studies, it is hypothesized that awareness on beef cattle fattening in the study area positively influence the adoption of beef fattening technology.

Attitude measures the degree of liking or disliking an individual has towards an object, idea or practice. The level of attitude towards beef cattle fattening was measured using a total attitude score of agro-pastoralists and pastoralists, which is continuous. Responses to a sample of questions in relation to beef cattle fattening were collected following a five point Likert type attitude scale. Negative statements were rated from one (1) for strongly disagree to five (5) for strongly agree. Then the total attitude score was worked out for each respondent and used for analysis. The sum of all responses for a respondent constituted a total score which characterized the respondent. Based on the aggregate score, an agro-pastoralist's and pastoralist' attitude towards beef cattle fattening was expected to be either positive or negative. Each respondent's attitude score was used as an independent variable in the Logit model.

The location of operations has been found to influence positively the adoption of technology (Sulo et al., 2012). Hall et al. (2009) found that location was positive and statistically significant $(\mathrm{P}=0.087)$ indicating that growers in the Midwest were 4.72 times more likely to adopt sustainable practices than other growers in other parts of the United States. According to Mlote et al. (2013) most of the beef cattle fattening operators in the Lake Zone in Tanzania are located in the rural areas (53.3\%) while $25.6 \%$ and $21.1 \%$ are located in urban and peri-urban respectively, often operating along the road side for easy access to services such as water and transport. In this model, the location of an enterprise is hypothesized to positively influence the adoption of beef cattle fattening.

Dependency on an activity as main source of income has positive influence on adoption of technology associated with that activity (Sulo et al., 2012; Johnson et al., 2010). According to Johnson et al. (2005) dependency on income from stocker positively impacted the probability in stocker operation where producers dependent upon income generated from stocker operation were $8.2 \%$ more likely to have long-term business plan. Vestal (2005) found producers depending on cow-calf income to be more likely to have a cow-calf business plan. In the study area, livestock is a major source of income. Thus the dependency on livestock as the main source of income was hypothesized to influence positively the adoption of beef cattle fattening technology.

The empirical model to assess factors that influence a respondent's willingness to adopt beef cattle fattening was therefore expressed using a binary regression as follows:

$$
y=\left[\begin{array}{l}
1: \text { adopted } \\
0: \text { Otherwise }
\end{array}\right]
$$

Following Garson (2009) and equation 6 above, the prediction equation is expressed as follows:

$$
\begin{aligned}
& y=\operatorname{In}(\text { odds }(\text { adopted })) \\
& =\operatorname{In}\left(\frac{\text { prob }(\text { adopted })}{\text { prob }(\text { otherwise })}\right) \\
& =\operatorname{In} \frac{(\text { prob }(\text { adopted })}{[1-\text { prob(adopted })]} \\
& =\beta_{0}+\beta_{1} X_{1}+\ldots . .+\beta_{K} X_{k}
\end{aligned}
$$

Thus, the analytical model can be expressed as follows:

$$
\begin{aligned}
& Y=\beta_{0}+\beta_{1} \text { age }+\beta_{2} \text { gend }+\beta_{3} \text { marit }+\beta_{4} \text { hhsize }+\beta_{5} \text { edu }+\beta_{6} \text { herdsize } \\
& +\beta_{7} \text { altitude }+\beta_{8} \text { aware }+\beta_{9} \text { msi }+\beta_{10} \text { loc }+\varepsilon
\end{aligned}
$$

Where,

$\mathrm{Y}$ is the probability of adoption; $\beta_{0}$ constant term, $\beta_{1} \ldots \beta_{10}$ are coefficients to be estimated, $\varepsilon$ is error term.

Equation 12 was run using STATA 10.1 to analyze the probability of adopting beef cattle fattening against the explanatory variables. Table 1 below summarizes the descriptive statistics of these variables. 
Table1. Description of variables used in the binary logistic model

\begin{tabular}{|c|c|c|c|c|}
\hline Variable type & Description & $\begin{array}{l}\text { How variable was } \\
\text { inputted }\end{array}$ & Mean & Std \\
\hline & Dependent & & & \\
\hline \multirow[t]{4}{*}{ Explained variable } & $\begin{array}{l}\text { Willingness to adopt beef cattle fattening } \\
\text { (y) }\end{array}$ & $\mathrm{Yes}=1 ; \mathrm{No}=0$ & 0.94 & 0.2 \\
\hline & Independent & & & \\
\hline & Age of the respondent (age) & Number of years & 51.6 & 13.3 \\
\hline & Gender (gend) & $1=$ Male; $2=$ Female & 1.2 & 0.4 \\
\hline \multirow[t]{3}{*}{ Characteristic of farmers } & Marital status (marit) & $\begin{array}{l}\text { 1=Married; } \\
\text { otherwise }\end{array}$ & & \\
\hline & Household size (hhsize) & $\begin{array}{l}\text { Number of family } \\
\text { members }\end{array}$ & 15 & 9.9 \\
\hline & Education level of household head (edu) & Year of schooling & 4.7 & 3.3 \\
\hline \multirow[t]{4}{*}{ Technological induction factor } & $\begin{array}{l}\text { Herd size or number of livestock } \\
\text { (Herdsize) }\end{array}$ & Livestock Units & 116.3 & 196.5 \\
\hline & $\begin{array}{l}\text { Livestock should be fattened first before } \\
\text { selling in order to get higher prices }\end{array}$ & $\begin{array}{l}\text { Strongly disagree }=1 \\
\text { Strongly agree }=5\end{array}$ & & \\
\hline & $\begin{array}{l}\text { A few productive animals can provide } \\
\text { higher income than many unproductive } \\
\text { animals }\end{array}$ & $\begin{array}{l}\text { Strongly disagree }=1 ; \\
\text { Strongly agree }=5\end{array}$ & & \\
\hline & $\begin{array}{l}\text { The number of animals is the most } \\
\text { important way to accumulate of wealth }\end{array}$ & $\begin{array}{l}\text { Strongly disagree }=1 \\
\text { Strongly agree }=5\end{array}$ & 29.1 & 7.9 \\
\hline \multirow[t]{4}{*}{$\begin{array}{l}\text { Attitude factors towards beef cattle } \\
\text { fattening (Alt) }\end{array}$} & $\begin{array}{l}\text { Commercial selling of livestock } \\
\text { predispose towards poverty }\end{array}$ & $\begin{array}{l}\text { Strongly disagree }=1 \\
\text { Strongly agree }=5\end{array}$ & & \\
\hline & $\begin{array}{l}\text { Young and immature animals should be } \\
\text { sold to get good profit }\end{array}$ & $\begin{array}{l}\text { Strongly disagree }=1 \\
\text { Strongly agree }=5\end{array}$ & & \\
\hline & $\begin{array}{l}\text { Commercial selling of livestock is a way } \\
\text { to become rich }\end{array}$ & $\begin{array}{l}\text { Strongly disagree }=1 ; \\
\text { Strongly agree }=5\end{array}$ & & \\
\hline & $\begin{array}{l}\text { Decision to sell animals should be } \\
\text { restricted to unproductive animals-barren }\end{array}$ & $\begin{array}{l}\text { Strongly disagree }=1 \\
\text { Strongly agree }=5\end{array}$ & & \\
\hline \multirow[t]{3}{*}{ Other factors } & $\begin{array}{l}\text { Awareness about beef cattle fattening } \\
\text { (aware) }\end{array}$ & $\mathrm{Yes}=1 ; \mathrm{No}=0$ & 0.96 & 0.2 \\
\hline & Main source of income (msi) & $\begin{array}{l}1=\quad \text { Livestock; } \quad 0= \\
\text { otherwise }\end{array}$ & 0.27 & 0.5 \\
\hline & Location of the respondents (loc) & $\begin{array}{l}1=\text { Urban; } \\
0=\text { otherwise }\end{array}$ & 0.89 & 0.3 \\
\hline
\end{tabular}

\subsection{Study Location and Data Collection}

Data for this study were collected from Agro-pastoralists and Pastoralist in Mwanza and Shinyanga regions in the Lake zone in Tanzania where according to MLDF (2012) beef cattle fattening is mainly practiced in the country. Geographically, Mwanza region lies between latitudes $1^{\circ} 30^{\prime} 3^{\prime \prime}$ South of Equator and $31^{\circ} 45^{\prime} 34^{\prime \prime}$ East of Greenwich, while Shinyanga region is located at $03^{\circ} 39^{\prime} 43^{\prime \prime}$ South and $33^{\circ} 25^{\prime} 23^{\prime \prime}$ East. The sampling frame included all Agro-pastoaralist and Pastoralist in the selected districts of Magu, Nyamagana and Sengerema in Mwanza region and Kahama, Kishapu, Meatu, Bariadi and Maswa districts in Shinyanga region as shown in Figure 1. The list of agro-pastoralist and pastoralist was obtained from the respective village registration book, from which 401 respondents (50 respondents from each district except one district where there were 51 respondents) were randomly selected. Global Positioning System (GPS) devices were used to geo-reference all points where the interviews were held. 


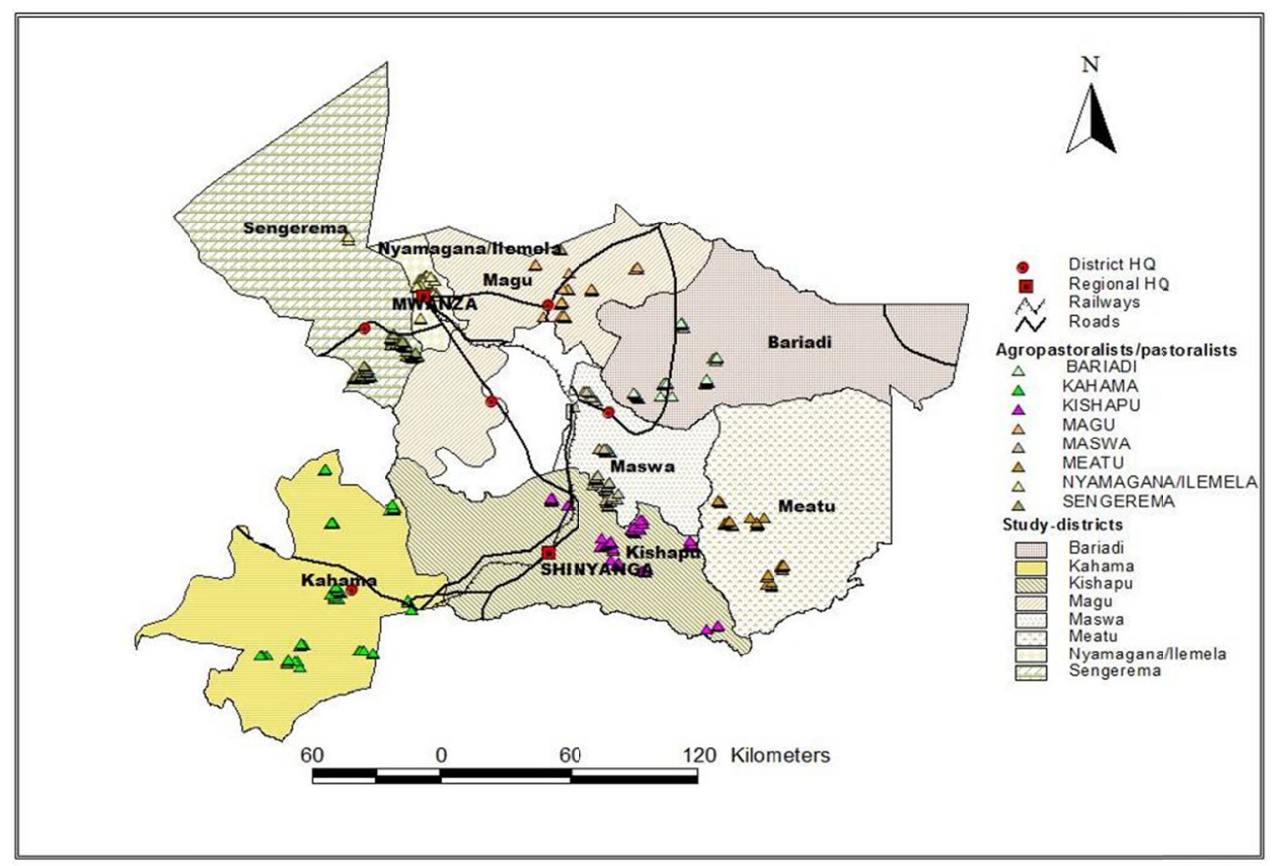

Figure 1. Location of Agro-pastoralists and Pastoralists in the study area

A structured questionnaire which included questions for the Likert scale and open-ended questions in relation to the respondents' personal characteristics, awareness and sources of income was used to collect data through face to face interviews. Within the Lake zone, most of the beef cattle fattening activities are conducted during the dry season. Field data were therefore collected by the principal researcher during the dry season between July and September, 2011, with the assistance of local experienced interviewers who were adequately trained prior to the surveys.

\section{Model Evaluation}

Data for this study are cross-sectional and are more likely to be affected by heteroskedasticity. Two methods were used to determine whether or not the data were heteroskedacitic. First, a visual inspection was conducted by plotting the residuals against the fitted values. The scatter graph indicated non-constant variances. The Breusch-Pagan test was then applied to the data as a post-estimation test of an OLS regression model under the null hypothesis that there was constant variance or no heteroskedasicity. The test rejected the null hypothesis $\left(\mathrm{Chi}^{2}(1)=372.71\right.$ with prob $\left.\left.\mathrm{Chi}^{2}=0.0000\right)\right)$ for adopting beef cattle fattening, indicating that there was a problem of heteroskedasticity. To improve the efficiency of hypothesis testing, heteroskedasticity-robust variances were used to calculate robust standard errors for correcting the problem (Green, 2000).

The multicolinearity problem was tested using the variance inflation factor (VIF) and results indicated that VIF values were below the minimum threshold of 5 with a mean VIF of 1.27 which indicates that there was no multicolinearity problem.

\section{Results and Discussion}

\subsection{Demographic Characteristics of Livestock Farmers and Operations}

The agro-pastoralists and pastoralists age were above 20 years old with the majority (49.6\%) being between 20 to 61 years old and were predominantly male $(84.54 \%)$. Most of them had primary education $(60.6 \%)$, while 24.7 percent had not attended school at all, $8.48 \%$ had an adult education, 5.74 had secondary education and only $0.5 \%$ had college education. The majority of the agro-pastoralists/pastoralists were married (90.27\%) (Table 2). 
Table 2. Demographic characteristics of respondents $(\mathrm{N}=401)$

\begin{tabular}{lcc}
\hline & Number of Respondents & (\%) \\
\hline Age of respondents (years) & & \\
20 to 40 years & 95 & 23.7 \\
41 to 60 years & 199 & 49.6 \\
$>$ 61years & 107 & 26.7 \\
Sex & & \\
Male & 339 & 84.5 \\
Female & 62 & 15.5 \\
Education level & & \\
Not gone to school & 99 & 24.7 \\
Adult education & 34 & 8.5 \\
Primary Education & 243 & 60.6 \\
Secondary Education & 23 & 5.7 \\
College/University & 2 & 0.5 \\
Marital status & & \\
Married & 362 & 90.3 \\
Single, divorced or widowed & 39 & 9.7 \\
\hline
\end{tabular}

About $88.5 \%$ of the respondents came from rural areas (Table 3). More than two thirds (70.3\%) of the respondents reported crop production as their main source of income, while $26.9 \%$ largely depended on livestock as the main source of income. Employment and other sources of income accounted for less than $1.75 \%$ (Table 3). Most of the respondents reported their occupation to be crop farming (94.26\%) followed by employment (8\%), businessmen $(8 \%)$, while $7 \%$ of the respondents reported to have no other business apart from livestock (Table 3). Close to one half of the respondents $(47.13 \%)$ had herd size or livestock unit of over 100 animals, 25.94 percent of the respondents had herd size between 51 and 100 animals while $26.93 \%$ of the respondents had herd size equal to 50 animals or below (Table 3). According to National Bureau of Statistics (NBS) which is responsible for national census in the country, large scale livestock farmers involves all farmers who own 50 animals and above, while small scale farmers are those owning animals below 50 . This means $74.06 \%$ of the respondents in the study area were large scale farmers who would be expected to adopt new technologies (Kaliba, Verkijl, \& Mwangi, 2000).

Table 3. Demographic characteristics of respondents' operation ( $\mathrm{N}=401)$

\begin{tabular}{lll}
\hline Item & Number of respondents & $(\%)$ \\
\hline Location & & \\
Urban & 46 & 11.57 \\
Rural & 355 & 88.53 \\
Main source of Income & & \\
Livestock & 108 & 26.93 \\
Crops & 282 & 70.32 \\
Employee & 7 & 1.75 \\
Others & 4 & 1.00 \\
Occupation & & \\
None & 7 & 1.75 \\
Employee & 8 & 2.00 \\
crop farmer & 378 & 94.26 \\
Business man & 8 & 2.00 \\
Herd size & & \\
$\geq 50$ animals & 108 & 26.93 \\
51 to 100 animals & 104 & 25.94 \\
$\leq 101$ animals & 189 & 47.13 \\
\hline
\end{tabular}


Overwhelmingly, 95.5\% of the respondents had heard about beef cattle fattening (Table 4). The majority (93.5\%) also viewed beef cattle fattening as "very important" especially this time when agro-pastoralists and pastoralists are under pressure for resource degradation caused by world climatic change leading to limited grazing land for animals and hence, they said "yes" they would like to adopt beef cattle fattening if given an opportunity. The main reason is that desertification, which is now accelerating in Sub-Saharan Africa at a rate that is more rapidly than before (Tamrat, 2007), a situation calling for change in livestock management systems. Out of the 93.5 percent of the respondents who indicated willingness to fatten beef cattle, $14.7 \%$ had started fattening their cattle already (Table 4). The majority of the respondents (78\%) who started fattening beef cattle indicated to have capacity to fatten up to 30 animals per fattening cycle of two to three months, while 13.6 percent of the respondents indicated to have capacity of fattening up to 50 animals. The remaining 8.4 percent of the respondents indicated to fatten animals up to 100 (Table 5).

Table 4. Awareness and adoption of beef cattle fattening $(\mathrm{N}=401)$

\begin{tabular}{lll}
\hline Item & Number of respondents & Percent of total \\
\hline Aware about beef cattle fattening & 383 & 95.5 \\
Aware and willing to adopt fattening if given an opportunity & 375 & 93.5 \\
Aware and started fattening without any assistance & 59 & 14.7 \\
\hline
\end{tabular}

Source: Field survey, 2011/2012.

Table 5. Capacity of Agro-pastoralists/pastoralists to fatten beef cattle ( $\mathrm{N}=59)$

\begin{tabular}{lll}
\hline Beef cattle fattening capacity & Frequency & Percent \\
\hline 1 to 30 animals & 46 & 78 \\
31 to 50 animals & 8 & 13.6 \\
51 to 100 animals & 5 & 8.4 \\
101 to 200 animals & 0 & 0 \\
Total & 59 & 100 \\
\hline
\end{tabular}

Source: Field survey, 2011/12.

\subsection{Constraints to Beef Cattle Fattening}

The respondents were also asked to indicate and rank constraints limiting them from practicing beef cattle fattening in their locality. The first ranked problem was lack of fattening skills $(22.8 \%)$ followed by low availability of credit $(20.5 \%)$, high fattening costs (17.1\%), availability of beef cattle fattening feeds (14.2\%), equipped area for fattening (12.5\%) and other factors which were below 5 percent as shown in Table 6.

Table 6. Responses on constraints and challenges associated to the adoption of beef cattle fattening by percentage and ranks $(\mathrm{N}=401)$

\begin{tabular}{lll}
\hline Constraint & Frequency & $(\%)$ \\
\hline Lack of fattening skills & 144 & 22.8 \\
Lack of credit & 130 & 20.5 \\
High costs of fattening & 108 & 17.1 \\
Limited availability of feeds & 90 & 14.2 \\
Lack of equipped area for fattening & 79 & 12.5 \\
Long distance to beef cattle fattening feeds & 20 & 3.2 \\
High transport costs & 18 & 2.8 \\
Lack of awareness creation & 15 & 2.4 \\
High treatment costs & 10 & 1.6 \\
Prevalent of livestock diseases & 5 & 0.8 \\
Shortage of extension officers & 5 & 0.8 \\
Tediousness of fattening activity & 5 & 0.8 \\
Lack of FMD vaccination & 3 & 0.5 \\
Lack of markets for fattened beef cattle & 1 & 0.2 \\
\hline Total & & 100
\end{tabular}

Source: Field Survey 2011/12. 


\subsection{Determinants for Agro-Pastoralists/Pastoralists Willingness to Fatten Beef Cattle}

The binary logistic model estimated to determine whether the agro-pastoralists/pastoralists are willing to adopt beef cattle fattening against explanatory variables of demographic characteristics, technological factors, agro-pastoralists attitudes and other factors along with the marginal effects are presented in Table 7. The model was significant $\left(\chi^{2}=45.65, \mathrm{P}=0.0000\right)$ correctly predicting $69.5 \%$ of the observations. The McFadden's pseudo $\mathrm{R}^{2}$ was 0.2781 . This is within the highly satisfactory range of 0.2 to 0.4 (Langer, 2000).

Table 7. Estimates of logit model explaining factors affecting adoption $(\mathrm{N}=401)$

\begin{tabular}{llllll}
\hline Variable & Coefficient & S.E & $z$ & P-value & $\begin{array}{l}\text { Marginal effects } \\
(\mathrm{dy} / \mathrm{dx})\end{array}$ \\
\hline Age & -0.015 & 0.02 & -0.72 & 0.471 & -0.015 \\
Gend & 1.278 & 0.839 & 1.52 & 0.128 & 0.033 \\
Marit & $1.376^{*}$ & 0.767 & 1.8 & 0.073 & 0.063 \\
Hhsize & 0.003 & 0.032 & 0.11 & 0.916 & 0.000 \\
Edu & -0.079 & 0.082 & -0.97 & 0.334 & -0.002 \\
Herdsize & -0.001 & 0.001 & -0.64 & 0.523 & 0.000 \\
Aware & $1.852^{* *}$ & 0.903 & 2.05 & 0.040 & 0.113 \\
Attitude & $0.152^{* * *}$ & 0.025 & 6.06 & 0.000 & 0.004 \\
Msi & 1.446 & 1.251 & 1.16 & 0.248 & 0.073 \\
Loc & 0.534 & 0.64 & 0.83 & 0.404 & 0.017 \\
Constant & -6.012 & 2.765 & -2.17 & 0.030 & \\
\hline
\end{tabular}

Wald $\mathrm{Chi}^{2}(10)=45.65 ;$ Prob $>\mathrm{Chi}^{2}=0.000 ;$ Pseudo $\mathrm{R}^{2}=0.2781 ;$ Log pseudo likelihood=-69.494339;

$*, * *, * *$ indicates significance levels at $0.1,0.05$ and 0.01 respectively.

The results in Table 7 indicate that all variables had the expected signs as it was hypothesized in the methodology section, except education which had a negative sign. The negative sign for education can be explained by the fact that, educated people in the study area were rarely involved in livestock keeping. About $93.77 \%$ of the respondents in the study area were either standard seven or below (Table 2). Three variables; marital status, awareness and attitude had a significant effect on the probability of a respondent adopting the technology. A respondent's marital status had a significant positive effect on the likelihood and magnitude of beef cattle fattening adoption. This result is consistent with Kilima et al. (2010) who found marital status to have a significant effect on adoption of improved agricultural technologies by smallholder maize and sorghum farmers in central Tanzania. If the household head was married, the probability of adopting beef cattle fattening technology rose by $0.063(6.3 \%)$. This means a married couple is more likely to adopt beef cattle fattening technology than singles.

The significant and positive coefficient for awareness results is a sign which implies that; creating awareness among agro-pastoralist and pastoralists regarding beef cattle fattening would increase the likelihood of adoption by $0.113(11.3 \%)$. This means that creating awareness is an important factor for scaling up this technology. This finding is consistent with the findings by Emukule et al. (2011) who established that the respondents' awareness about the product was positive and significantly influenced their willingness to pay for camel milk in Nakuru District in Kenya.

The agro-pastoralists attitude towards beef cattle fattening was also positive and significant at $\mathrm{P}<0.01$ as hypothesized indicating that the attitude of agro-pastoralists and pastoralists positively influence the adoption of beef cattle fattening technology in the study area. The marginal effects for attitude indicate that a unit change in attitude towards beef cattle fattening would increase the probability of adopting beef cattle fattening technology by $0.3 \%$.

Age, Gender, Household size, Herd size, Main source of income and the location of respondents though had the expected sign as hypothesized in the methodology section, but, they did not have any significant effect on adopting beef cattle fattening technology in the study area. 


\section{Conclusions and Policy Implications}

The findings of the study suggest that $95.5 \%$ of agro-pastoralist and pastoralists are willing to adopt beef cattle fattening, $14.7 \%$ out of that had already started fattening their cattle, ranging from 30 to 100 animals per fattening cycle of three to four months. The results of Logit analysis show that a respondent's decision to adopt beef cattle fattening was strongly influenced by their marital status, their awareness and attitude towards cattle fattening. Therefore the hypothesis that awareness and positive attitude of the respondents towards beef cattle fattening will significantly influence adoption decision is accepted. A number of constraints limited the adoption or expansion of beef cattle fattening in the study area. These were lack of beef cattle fattening skills (22.8\%), lack of Credit (20.5\%), high costs of fattening (17.06\%), low availability feeds (14.22\%), inadequate facilities and equipment at fattening sites (12.43) among others as indicated in Table 6.

The adoption of beef cattle fattening by agro-pastoralist/pastoralists is expected to improve the beef cattle value chain not only to the Lake Zone regions, but also to the whole country and that the actors along the chain including the producers and consumers are going to benefit significantly (Mlote et al., 2013). These are farmers who have information (aware) about beef cattle fattening and they have a positive attitude towards about it. This study provides enough bases for researchers and policy makers within the Ministry of Livestock and Fisheries Development to conduct further research geared towards designing, promoting and helping to develop a vibrant and effective sub-sector of beef cattle fattening. Policy guidance may include guidelines in order to facilitate the specific target groups to engage in beef cattle fattening enterprises.

\section{References}

Akudugu, M. A., Guo, E., \& Dadzie, K. S. (2012). Adoption of modern agricultural production technologies by farm households in Ghana: What factors influence their decisions? Journal of Biology, Agriculture and Healthcare, 2(3), 224-3208.

Al-Hassan, R. M., Egyir, S. I, \& Abakah, J. (2013). Farm household level impacts of information communication technology (ICT)-based agricultural market information in Ghana. Journal of Development and Agricultural Economics, 5(4), 161-167.

Dzadze, P., Osei, M. J., Aidoo, R., \& Nurah, G. K. (2012). Factors determining access to formal credit in Ghana. A case study of small holder farmers in the Abura-Asebu Kwamankese district of central region of Ghana. Journal of Development and Agricultural Economics, 4(14), 416-423.

Emukule, J. I., Ngigi, M., \& Guliye, A. Y. (2011). Analysis of socio-economic factors influencing willingness to pay for camel milk in Nakuru district, Kenya. Livestock Research for Rural Development, 23(1).

Garson, G. D. (2009). Logistic regression. Retrieved 4 May, 2013, from http://www2.chass.ncsu.edu/garson/pa765/statnote.htm

Green, W. (2003). Econometric Analysis (5th ed.). New Jersey: Prentice Hall.

Green, W. H. (2008). Econometric Analysis (6th ed.). New Jersey: Prentice-Hall.

Hall, J. H., Dennis, J. H., Lopez, R. G., \& Marshall, M. I. (2009). Factors affecting growers willingness to adopt sustainable floriculture practices. HortScience, 44(5), 1346-1351

Howley, P., Donoghue, C. O., \& Heanue, K. (2012). Factors affecting Farmers' Adoption of Agricultural Innovations: A Panel Data Analysis of the Use of Artificial Insemination among Dairy farmers in Ireland. Journa of Agricultural Science, 4(6), 171-179. http://dx.doi.org/10.5539/jas.v4n6p171

Jing-na, T., \& Lu-tang, L. (2012). Factors influencing willingness and ability of farmers to adopt new technologies: A case study of Guanzhong Area. Asian Agricultural Research Journal, 4(7), 37-40.

Johnson, R. J., Doye, D., Lalman, D. L., Peel, D. S., Raper, K. C., \& Chung, C. (2010). Factors affecting adoption of recommended management practices in stocker cattle production. Journal of Agricultural and Applied Economics, 42(1), 15-20.

Kaaya, H., Bashaasha, B., \& Mutetikka, D. (2005). Determinants of utilization of Artificial Insemination services among Ugandan dairy farmers. African crop science conference proceedings, 7, 561-567.

Kafle, B. (2010). Determinants of adoption of improved maize varieties in developing countries. A review. International Research Journal of Applied and Basic Sciences, 1(1), 1-7.

Kaliba, A. R. M., Verkuijl, H., \& Mwangi, W. (2000). Factors affecting adoption of improved maize seeds and use of inorganic fertilizer for maize production in the intermediate and lowland zones of Tanzania. Journal of agricultural and applied Economics, 32(1), 35-47. 
Kennedy, P. (1998). A guide to Econometrics (4th ed.). Cambridge: The MIT Press.

Kilima, F. T. M., Mbiha, E. R., Erbaugh, J. M., \& Larson, D. W. (2010). Adoption of improved agricultural technologies by smallholder maize and Sorghum Farmers in Central Tanzania. Eastern and Southern Africa Journal of Agricultural Economics and Development, 7.

Langer, W. (2000). The assessment of Fit in the class of Logistic regression models. A pathway out of the jungle of Pseudo-R2s. Martin-Luther-University of Halle-wittenberg Institute of Sociology. Retrieved from http://www.socziologie.uni-halle.de/langer/pdf/papers

MLD (Ministry of Livestock Development). (2006). National Livestock Policy (NLP). Retrieved from http://www.mifugouvuvi.go.tz

MLFD (Ministry of Livestock and Fisheries Development) (2013). Budget speech 2012/13. Retrieved from http://www.mifugouvuvi.go.tz/

MLFD (Ministry of Livestock and Fisheries Development). (2011). Investment opportunities in the livestock industry. Retrieved from http://www.mifugo.go.tz/documents-storage/investmentopportunity. PDF

MLFD (Ministry of Livestock and Fisheries Development). (2012). Budget speech 2012/13. Retrieved from http://www.mifugouvuvi.go.tz/

Mlote, S. N., Mdoe, N. S. Y, Isinika, A. C., \& Mtenga, L. A. (2013). Profitability analysis of small scale beef cattle fattening in the Lake Zone in Tanzania. Journal of Agric. Economics and Development, 2(5), 203-216.

NSCA (National Sample Census of Agriculture). (2007/2008). Government document Produced by National Bureau of Statistics in collaboration with Ministry of Agricuture, Food Security and Cooperatives, Ministry of Water and Irrigation, Ministry of Livestock and Fisheries Development, Ministry of Industry and Marketing, Prime Minister's Office, Regional Administration and Local Government, Office of the Chief Government Statistician Zanzibar, and Ministry of Agriculture, Livestock and Environment, Zanzibar. Retrieved from http://www.africalivestockdata.org/afrilivestock/sites/africalivestockdata.org/files/LDIA_Brief_2011_04.pd $\mathrm{f}$

Pindyck, S. R., \& Rubinfeld, L. D. (1998). Econometric Models and Economic Forecasts (4th ed.). New York: McGraw-Hill.

Prokopy, L. S., Floress, K., Klotthor-Weinkauf, \& Baumgart-Getz. (2008). Determinants of agricultural best management practice adoption: Evidence from the literature. Journal of Soil and Water Conservation, 63, 5, 300-311. http://dx.doi.org/10.2489/jswc.63.5.300.

Qualls, D. J. (2011). Analysis of Factors affecting Farmers' willingness to adopt switch grass production in the Sothern United States and an Excel spreadsheet-based decision tool for potential switch grass producers. Master's Thesis, University of Tennessee. Retrieved from http://trace.tennessee.edu/utk_gradthes/933

Rahm, M. R., \& Huffman, W. E. (1984). The adoption of reduced tillage: The role of Human Capital and Other Variables. American Journal of Agricultural Economics, 66(4), 405-413. http://dx.doi.org/10.2307/1240918

Rogers, E. M. (2003). Diffusion of Innovations (5th ed.). New York: The Free Press.

Sajjad, M., Saif, M. I., \& Humayoun, A. A. (2009). Adoption of Information Technology: Measuring Social Influence for Senior Executive's. American Journal of Scientific Research, 81-89. Retrieved from http://www.eurojournals.com/ajsr.htm

SAS. (1994). SAS/STAT User's guide. Vol. 1.

Sulo, T., Koech, P., Chumo, C., \& Chepng'eno, W. (2012). Socio-economic factors affecting the adoption of improved agricultural technologies among women in Marakwet County, Kenya. Journal of emerging trends in economics and management sciences (JETEMS), 3(4), 312-317.

Tamrat, Z. (2007). Adoption of small ruminant's fattening package in agro-pastoral areas, Meiso Wereda, Eastern Oromia. A thesis submitted to the Department of Rural Development and Agricultural Extension School of Graduate Studies, Haramaya University. In partial fulfillment of the requirements for the degree of Master of Science in Agriculture.

Vestal, M. K. (2005). Production Practices and Mangement Intensity of Oklahoma Cow-Calf Producers across Income and Herd Size. Master's Thesis. Departiment of Agricultural Economics, Oklahoma sate University. 
Ward, C. E., Vestal, M. K., Doye, D. G., \& Lalman, D. L. (2008). Factors affecting adoption of cow-calf production practices in Oklahoma. Journal of Agricultural and Applied Economics, 40(3), 851-863.

Zomoi, J. N., Byaruhanga, J. K., Maritim, H. K., \& Omboto, P. I. (2007). Determinants of technology adoption in the production of horticultural export produce in Kenya. African Journal of Business Management, 1(5), 129-135.

\section{Copyrights}

Copyright for this article is retained by the author(s), with first publication rights granted to the journal.

This is an open-access article distributed under the terms and conditions of the Creative Commons Attribution license (http://creativecommons.org/licenses/by/3.0/). 